\title{
The Indonesian Forestry in Economic, Ecosystem and Legal Perspectives
}

\author{
Dr. Wahyu Wiriadinata \\ Lecturer, Faculty of Law, University of Pasundan \\ Korespondensi mengenai artikel ini harus dialamatkan kepada \\ Wahyu Wiriadinata, Jl. Idi Adimaja I No. 1 Bandung \\ E-mail: wahyuwiriadinata@yahoo.co.id
}

Accepted: March 13, 2014

Doi:10.5296/ jpag.v4i1.5450 URL: http://dx.doi.org/10.5296/ jpag.v4i1.5450

\begin{abstract}
Forest and forestry are strategic factors, because the forest existence in Indonesia as the world lung and it can maintain ecosystem equilibrium. Destruction in Indonesian's forest can also affect and result in destruction in living environment.

The forestry of Indonesia is in fact, especially in Borneo region has largely reduced and destructed. Its biological heterogeneity has substantially been eliminated, too. This instance is, among other, caused by people's shifting cultivation, illegal cuttings by local peoples, illegal cutting and logging by the Forest Managing Rights and its slash and burn.

This article is written from literature research findings presented in analytical descriptive form. The objective of this article presentation is to provide an illustration and true condition about the Indonesian's forest as an important strategic factor, where the forest itself and forestry has valuable role and serve as medium for maintaining the ecosystem equilibrium and preserve the world environmental life, especially in Indonesia itself and the most important objective of this research may be contribute a valuable benefit for entire scientific world and especially for the science of law.

For preventing of the continuous forestry destruction and its recovery, it is important to make protective steps through legal instruments by appropriate and fair sanction enforcement, pursuant to the 41 Act of 1999 about Forestry, formulation of legal offense and the forestry criminal acts contained in Article 50. The heaviest sanction is 15 years in jail punishment and its highest fine is Rp. 10 billions and rehabilitation by reforestation.
\end{abstract}

Keywords: Forest destruction, prevention, recovery 


\section{Introduction}

The forest is an area as part of the most important living environmental cycle for our earth survival. It is due to fact that such forest is an area above this earth that can regulate ecosystem equilibrium. Forest destruction as occurred in Indonesia, especially in Borneo is a kind of world disaster, because it can damage ecosystem. The damaged forest in Borneo is primarily caused by two factors; they are illegal cutting and logging.

It is clearly shown by experience that forest and forestry existence have important role for life environment and Indonesian peoples existence and survival as well as human beings, for examples:

1. Forest and forestry are life support systems. Without this buffer, thus the supported will be fallen and broken. For instance, a good and normal waters system will support entirely economic sectors such as agricultural, fishing, husbandry sectors, or a variety of manufacturing and service industries. A good and stable climate will be able to keep and improve all sectors productivity. Otherwise, if such forest is destructive, it is possible to occur a variety of disastrous occurrence such as: flood, erosion, landslide, drought, and increased world temperatures or global warming that in turns to reduce productivity and appearance of various human being, plants and animal epidemics.

2. In economic sector, forestry has a very high advantages in Indonesian national development, where :

a. Forestry could and had ever become the second largest foreign currency contributor following the petroleum; it can provide approximately $\$ 7$ billions ${ }^{1}$. From changes in Indonesia position to be petroleum net-importing country, forestry can potentially become the largest foreign currency contributor for Indonesia. Demand for wood products and their price tend continuously to go up, and there is no other commodity has stable expanding market as such these wood products.

b. For Indonesia as a developing country, comparative and competitive advantages owned by Indonesia is only in its natural resources endowment with its substantial volume and good quality, but have not connected with its human resources, capital and technological ones. Consequently, forestry sector is a strategic one for Indonesian economy, beside as life environmental keeping instruments and ecosystem balancing system, it has currently occurred changes in Indonesian's forest as such in Sumatera, Borneo, or Papua, and consequently Indonesian forestry size as the world lung and ecosystem balancing system has reduced and it will threaten the world from global warming.

It has been available various preventive actions performed by the Government of Indonesia, both individual initiatives and joint initiatives with other countries. Those prevention efforts themselves are, among other, conducted with judicial instruments, such through the 41 Act of 1999 about Forestry as, where it is said in Article 50 that;

\footnotetext{
${ }^{1}$ Dudung Darusman, Peranan Hutan Tanaman Bagi Masa Depan Kehuitan Indonesia, Paper : presented in Seminar performed by the Perhutani, Bandung, October 2008, page 1.
} 
1) Everybody is prohibited to destruct forest protective infrastructures and means.

2) Everybody is given a business license to make use area utilization, business license for environmental service utilization, business license for wood and non-wood product utilization, as well as license for wood and non-wood product collection, prohibited to conduct activities resulting in forestry destruction.

3) Everybody is not permitted to :

a. manage and or make use and or occupy a forestry area in illegal way;

b. log forest area;

c.operate tree cutting in a forest area within radius or distance up to :

1. 500 (five hundreds) meters from dam or lake banks;

2. 200 (two hundreds) meters from well and river's right-and left-hand bank in swamp area;

3. 100 (one hundreds) meters from river's left-right bank.

4. 50 (fifty) meters from tributaries' left-right bank.

5. 2 (two) times of ravine depth from its bank.

6. 130 (one hundred thirty) times of differences between the highest and lowest tides.

d. slash and burn the forest;

e. Cut trees or harvest or collect forestry products within it without any rights and permissions from the authorized officials.

f. receive, buy and sell, barter, accept consignment, store or possess forestry products that is understood or assumed coming from forest area where their harvesting and collecting is illegal;

g. make general investigation or exploration activities or exploitation of mining materials within forest area without any license from related Minister;

h. transport, hold, or take in forest product possession that is not simultaneously accompanied with documents about forest product's valid information letter;

i. tend livestocks within a forest area not specifically intended for such purposes by authorized officials;

j. Bring heavy instruments and or tools that are not accepted generally or may be guessed to be used for forest product transportation within forest area without any permission from authorized officials.

k. Bring instruments or tools that are generally made use to fell, cut, or divide trees within forest area without any permission from authorized officials. 
l. discharge things or materials that may result in combustion and destruction as well as threaten forest function existence and continuity into forest area; and bring out and transport plants and wild animals which is not completed with regulatory protection coming from forest area without any permission from authorized officials.

However, various protective efforts with judicial instruments as said above, it cannot in fact reach significant outcomes, because illegal cutting and logging within forest is actually remains to continue. Therefore, such forestry problems, especially concerning on illegal cutting and logging in forest to be interested for review because those problems said above is always actual issue.

From descriptions said above, thus it can be drawn identifications about some protruding issues, namely:

1. How far is the judicial instrumental effectiveness able to prevent illegal cutting dan logging in forest in Indonesia?

2. How extent is the judicial instrumental effectiveness in attempt to keep Indonesian's forestry preservation capable to maintain ecosystem equilibrium?

Meanwhile, the method used in writing this article is a literature research methodology with studying various related rules of regulation and, therefore, this article has analytical judicial descriptive character.

In addition, this article benefit may be providing benefit for scientific progress and especially in the science of law.

\section{Theoretical Framework}

Indonesia is a state of law as it was written down within the 1945 Constitution in Article 1 clause (3) stating that: "The Republic of Indonesia is a state of law". Therefore, it is clear that state of Indonesia is a state of law containing consequences that state-affair performance and societal issues would be performed on legal basis but not on power principle.

Furthermore, in Article 33 said that:

(1) The economic life is arranged as collective fortunes in accordance with familial principle.

(2) Production branches which has importance for state and dominate community life would be holded by state.

(3) Earth and water as well as natural endowment contained within it would be under state domination and they would be largely utilized for people's prosperity.

Even if we pay attention on clause (3) of this 1945 Constitution's Article 33, earth and waters as well as natural endowment contained within it must largely be utilized for people's prosperity. Consequently, forest and forestry sectors as Indonesia's natural endowment must largely be used for people's prosperity themselves. The objective of this people's prosperity is 
parallel with concepts and theories developed by K. C. Wheare, with the concept of welfare state. That state is responsible for reaching its citizenship and law prosperity. Throughout this concept or theory, it is expected that forest and forestry sectors may provide a large contribution for the people of Indonesia prosperity. It has also been addressed by the 1945 Constitution.

\section{The Condition of Indonesia Forest}

Indonesia has the largest and highest biological diversity in the world, although its land size is only 1.3 percents of the total earth surface. Its biological endowment accounts for 11 percents of entire vegetation species above the earth surface. In addition, there are also 10 percents of mammalian species from total earth mammalian and 16 percents species of bird in the world.

How large is total Indonesia forest? The Indonesia Forestry Authority in 1950 had ever released a vegetation map. Such map provides concise information that, there were approximately 84 percents total size land of Indonesia (162,290,000 hectares) in the past was enclosed by primary and secondary forest, including all types of plantation.

The 1950 vegetation map also stated that total forest in each large Indonesian's island are consecutively as following, Borneo has total forest area as 51,400,000 hectares, Irina Jaya, 40,000,000 hectares, Sumatera, 37,370,000 hectares, Sulawesi, 17,050,000 hectares, Molucca, 7,300,000 hectares, Java, 5,070,000 hectares and lastly Bali and Nusa Tenggara Barat/Timur consists of 4,400,000 hectares.

In the Dutch colonial era, large-scale plantation that has been exploited in 1939 had reached 2.5 millions hectares and among this land was only 1.2 millions hectares cultivated one. This sector perceived a stagnation period from 1940s to 1950 s. In 1969, total small-scale plantation sizes have only reached 4.6 million hectares. The majority of this forest land perceived a change function to be plantation and Richfield area in 1950s and 1960s. The primary reason for land opening in forest area occurred as consequence from agricultural interest, especially for rich cultural purpose.

In the 1970 period, forest in Indonesia moved to a new stage. In this period, deforestation (forest land disappearance) started to become a serious problem. Indeed, lumber industries were taking place a fast growth. Trees were assumed as brown golden with tempting profitability. Furthermore, forest cutting and felling was started to open in commercial ways. In that time, there was some illegal logging in the forest area, firstly intended to develop lumber production system for the future interest. This step was finally operated toward serious forest degradation. This condition is followed by other forest opening and converted to become other land consumption interest.

According to the survey conducted by government, it is said that coverage of forest reached 119 million hectare in 1985. If it is compared with total forest area in 1950, thus it has been perceiving a reduction about 27 percents. In 1970 and 1990 period, it was estimated deforestation rate ranges between 0.6 to 1.2 millions hectares. 
However, these figures were immediately corrected, when the government and the World Bank cooperated to make a re-mapping in 1999 on area of forest coverage. According to this 1999 survey, average deforestation rate reached 1.7 million hectare in 1985-1997 period. As long this period, Sulawesi, Sumatera, Borneo expressed the largest deforestation rate. These regional collectively lost more than 20 percents their respective forest coverage. Scientists also agreed that if this condition continuously takes place, non-swamp lowland forests will also disappear in Sumatera in 2005 and Borneo after 2010.

It was finally drawn a surprising conclusion. Total area of Indonesian's virgin forest perceived a depletion process in a very worrying rate. Until today, Indonesia has lost about 72 percents of its virgin forest (Sources: World Resource Institute, 1997).

In 1997 to 2000 period, it was found a new fact that forest depletion increased to become 3.8 million hectares in a year. It is two times compared with 1980 occurrence. This fact made Indonesia as one of places where take place the highest forest destruction in the world. In Indonesia, according to the 2000 landscape imaging interpretation output, there are available approximately 101, 73 millions hectares destructive forest and land, among them about 59.62 millions hectares stay within forest area (Baden Planologi Dephut, 2003). And it creates a worse Indonesia's forest condition portrait from ecological, economic and social perspectives.

The Indonesian Forest Watch in collaboration with the Global Forest Watch presented the first comprehensive evaluation report about Indonesia's forest condition. This report made its conclusion that deforestation rate took place two times where its primary reasons were caused by corrupted political and economic system that assume its natural endowment, especially its forest resources as state's revenue sources may be exploited for political and personal interests. The political instability that takes place following the 1997 economic crisis and finally sided down the Soeharto presidency position in 1998 create a higher deforestation rate up to current deforestation rate.

Substantial expansion in lumber and pulp and paper industries that took place for 20 years period cause at last an increasing demand on lumber raw material in this present time far exceeds its legal supply. This gap reaches 40 million cubical meters in a year. There are many lumber processing industries which recognize their dependence on surreptitious (illegal) wood, totaling to 65 percents from the 2000 total supply.

The problem in this serious Indonesia's forestry issue must be looked for its solution.

\section{The Condition of Borneo Forest}

The world large oxigeneous concentration in Kalimantan Island perceives a rapid depletion as consequence from expansion in oil palm plantation area and illegal logging, causing a reduction in tropical forest area and it is a primary factor of global warming. Unfortunately, a part of our earth lungs perceives a shrinkage process.

This Kalimantan Island is the third largest island in the world and the largest one in Asia, and it is also one island under three national administrations, namely, Indonesia, Malays, and Brunei Darussalam. Indonesia itself accounts for the largest territorial portions with 4 
provincial administration that claim two third of this total island area. Malays stay in the second position (with two states, Sabah and Sarawak) and Brunei Darussalam itself only claims a pity area, with total area approximately $743.33 \mathrm{~km}^{2}$. However, its petroleum and natural content may create this country as the richest nation in Asia.

Since former times, primary traffic in the hinterland of Borneo Island relied on river transportation mode. Even a part of river transportation in hinterland area serves as important traffic mode in abroad communication. Inter-river distance in Northern Borneo region that could be travelled by ship is maximally as $160 \mathrm{kms}$ long. This situation make mountainous region in the hinterland area is not penetrable with river transportation mode, so it has not been reached by modern community.

Dry and wet equator climate is divided into two seasons. From October to March as rainy season, and the remainder as dry season with somewhat dry and calm condition. Its average yearly rainfall is about $3,800 \mathrm{~mm}$, having various natural biological endowment, including more than 10 species primate, 350 bird species, more than 150 crawl and amphibical animal species and 15,000 flora species. Kalimantan is also home for a variety of dangerous threading species such as Orang Utan, Malayan bear and rhinoceros.

Not long past time, the WWF declared that since 1996 it was found 361 new species in Kalimantan, it is minimally found 3 new species in a month and until today this region still store thousands of species which has not studied yet.

Stewart Chapman, coordinator of the WWF's international project, the Heart of Borneo, claimed that, "those findings again provide evidence that Kalimantan or Borneo is one of the most important biological diversity centers in the world".

The Sarawak tribes, a minority tribal group in this Kalimantan Island continuously fights to maintain their existence. The rapid world changes can't accommodate anymore their long traditional life-style. In coincidence with land opening for agricultural and plantation industrial commodity interests, primitive forests in this area is currently remained one half part, and natural resource development continuously take over their excellent land for survival.

The Sinar Mas Group possesses a very large forest concessionaries development rights in Province of Riau for supplying demand for pulp and paper industries. The forest logging in Province of Riau performed by Sinar Mas Group in a given year has resulted in 2.5 million tons $\mathrm{CO} 2$ discharge into earth atmosphere.

The Greenpeace group claimed that Sinar Mas Group has depleted millions hectar of land for its business interest. In Province of Riau, forest deforestation has resulted in the remaining forest land is leaved only 30 percents, in 1982 total forest area in this province is still approximately 78 percents. A document issued in 2007 by the Greenpeace group shows the Sinar Mas Group framework to increase its pulp mill capacity from 2.6 million tons a year to 17 millions tons.

Nomadic shifting farmer activity in Province of Riau oftenly slash and burn forest in attempt 
to open an empty land for economic-value cultivation commodity from plantation enterprise, but smokes from such forest slashing and burning activity brings bad impacts in Southeast Asia. For 13 years latest, this issue has obtained some thigh protest from surrounding countries such as Malaysia and Singapore which suffer from those smoke pollutant.

According to statistic report issued by the Government of Indonesia, it is stated that total area of oil palm plantation has reached 6.8 millions hectars, meaning it equals to 5 percents of total Indonesia territory. However, according to non-governmental organization (NGO), those figures are actually far above the government formal data.

The Sawit Watch - an Indonesian's independent environmental observating organization, there are approximately 18 millions tropical rainy forest has completely destructed for change with oil palm plants.

The group of life environmental watch appeals a larger power importance to prevent those plantation enterprise to do forest logging in Indonesia which is assumed to break the law, because if such actions is not given a follow-up attention, so our this earth ecosystem may be more threatened.

\section{The Forest's Destructive Causal Factors In Kalimantan}

\section{The Shifting Agricultural Habit}

As we all understand that land and soil resource quality in Southern Kalimantan for farming activity in mountainous area is very unoften one, so that if those area has been cultivated for two or three times in sequential repetitions, they will not be potential anymore, and it is suffered with very traditional agricultural technology. Consequently, a community led by Shifting Agricultural Head (Tribal Head) will open another land for new agricultural purpose to support their survival. ${ }^{2}$

This traditional process has been taking place for hundreds years or since Kalimantan population begun to have a specific culture until today. According to the IMPAS-B knowledge until to the end of 1980 period, there is no negative impact from such shifting agricultural activity because once those tribal population did land slash and burn, they always kept it around forest sides (meaning it may not be allowed to burn forest).

The opening of agricultural land in Kalimantan's Dayak tribes (forest occupants) is only for meeting their food consumption, not for commercial business, and they suffice their another needs by collecting whatever things has economic value in the forest. The shifting farmer always open a new forest land on seasonal and climate estimation basis. According to observation and based on just and civilized human considerations, the Kalimantan Dayak's tribes whom occupy forest area, farming is a natural needs for themselves.

The former agricultural land in forest outer side grown by grasses and young plants is a very important land needed by flora and fauna staying in virgin forest area, so this area may become a very harmonic ecosystem site. It is seen interdependence between human being,

\footnotetext{
2 Bambang Pamuliardi, Hukum Kehutanan dan Pembangunan Bidang Kehutanan, PT. Raja Grafindo Persada Publisher, Jakarta, November, 1994, page 280.
} 
vegetation and animals. Flora provides life for fauna and fauna disseminates flora.

The shifting agricultural activity does not naturally destruct an environment, meaning that even if it does actually exist, they are not forest destructive primary causal factor, because when they are slashing and burning it, it is always kept and they emotionally have ecological wisdom with environment as the place for searching of living sources.

\section{Illegal Logging}

In Old Order Period, the "illegal cutting or logging" term had not ever recognized, especially in Paramasan Bawah region. If occupants of forest area do farming activity for their rich consumption, for consumption and needs, they will only utilize other available forest resources.

Before Indonesian independence proclamation, community has understood and utilize forestry products by manual and traditional cutting practices. In those period, forest product trading as such lumber products are primarily conducted in local-scale barter market. Lumber products for home construction material is only used its bark because they had only a very minimal technology dan skill.

Peoples can not manually take lumber products with more than $500 \mathrm{~m}$ distance from tributaries, even if such products located in other mountain sides. Based on available data, there were no negative impacts coming from forest utilization activity conducted by local community since 1980 in Kalimantan forest that affect surrounding life for flora, fauna, and community. It is also true with burning and smoking forest where their effects did not appeared since 1980 .

\section{Cutting conducted by HPH's Holder}

Whatever we did with the forest, such as shifting agricultural practices, forest pathfinders, illegal logger, plantation area, construction material production, such as log lumbers as well as forest exploitation by HPH's holders will collectively affects ecosystems and destruct its habitat. Their differences is only seen in multitude of destruction occurred as consequence from forest exploitation.

The forest condition after HPH's holder exploitation in Kalimantan, especially in Regency of Banjar, Souther Kalimantan, possess complete, dense, crowded structures with large potential. This beautiful and harmony forest condition, in according to our observation requires for thousand years for their established recovery. ${ }^{3}$

Some kinds of plants live together to develop a unity of inter-protective forest environment. In a specific forest, if we see and read its surrounding in wisdom ways as if there is a harmonic integrative life, where individual plants support their growth each others. A specific plant life as if it is regulated to support other plant's survival.

The completely virgin forests will be very beautiful, bold, and imaging. Its plant leaves, branches and small branches grow crowdly each other to prevent sunshine may not loosely

\footnotetext{
${ }^{3}$ Salim H.S., Dasar-Dasar Hukum Kehutanan, Sinar Grafika Publisher, Mataram, 2002, page 148.
} 
penetrate into their trees. Leaves density has an important function, namely to protect underbrushes area under trees so that fallen leaves may decompose to be fertilizers and absorb water as rain water stock if dry season comes. This forest behavior is also as forest's attempt in natural ways to protect itself from burning risk.

Up to the end of 1960s, forest existence in Regency of Banjar, South Kalimantan is still classified as a bold crowded forest although there is manual exploitation by local peoples.

In the beginning 1970s, the HPH holder, PT. KADECO, started to bring its equipment into forest area for its exploration. These reliable equipments make forest condition suffered from them in a very short time, and then the "deforestrated" term begun well-known in community.

There has been non records about how many trees cutted and their cubical meter volume for more than 30 years period. We also not uncover how extent is the KKN criminal action occurred in forestry offices, unwise behavior in managing forest endowment or data and documentary manipulation in which there are many and many lumber products are not completed with authorized documents or lumber documents in total 2,000 $\mathrm{m}^{3}$ volume may protect same product in $10,000 \mathrm{~m}^{3}$ volume?

Our anxiety may be focused on natural behavioral changes if forest area can't serve as it is in normal condition, because its inability after fell and cut treatment for recovery or there is no effort to recover its function by rehabilitation and forestation acts. If those forests are not capable to accumulate water anymore, to keep its humidity in dry season in attempt to fight againt its burning possibility and as buffer area for flooding in rainy season in which water will accumulate in upstream area of local rivers at low tide period, thus it may be dangerous threat for environmental and ecosystem equilibrium.

\section{The Forest's slash and burn}

The forest's slash and burn activity is not only occurred in Kalimantan, but it is also took place in other forestry center in Indonesia, such as in Sumatera (Aceh, Riau, Jambi, and South Sumatera), Papua and Sulawesi (Central Sulawesi, Southern Sulawesi, and Southeastern Sulawesi). In generally, it is conducted by the HPH's holder in illegal and blind patterns. The forest's slash and burn is also made by shifting farmers.

The forest's slash and burn may result in a reduction in forest size within all Indonesia territory, it can also produce air pollution, because its smokes will pollute air in surrounding slashed and burned forests, and even it can produce air pollution in surrounding countries as such Malaysia, Singapore, Brunei Darussalam, New Guinea and Australia, too. This will make separated issue into surface, it is not only producing life environmental detruction but it can also create potential bilateral conflict. There are also complaints coming from non-governmental organizations, including the Greenpeace Group. ${ }^{4}$

\section{Prevention and Recovery}

The forest and forestry conditions as it is illustrated in above description have entered into

\footnotetext{
${ }^{4}$ Salim, H.S., Dasar-Dasar Hukum Kehutanan, Sinar Grafika, Mataram, 2002, page 158.
} 


\section{Macrothink}

Journal of Public Administration and Governance

ISSN 2161-7104

2014, Vol. 4, No. 1

critical and dangerous conditions for forestry survival and preservation as well as life environment. Consequently, those conditions may not be allowed to continue and must be stopped as soon as possible. Alternatively, in order to prevent succeeding destruction and forests that has been destructed one, so it must urgently made some recovery efforts.

\section{Prevention}

Protection from forest destruction in Indonesia may be started from production of legal instruments, where forest destruction in especially for illegal logging as a criminal action. This instance is regulated within legislation as such Acts About Forestry Issue. Meanwhile offensive formulation from those forestry crimes is, among other, formulated in Article 50 of the 41 Act of 1999:

1) Everybody is prohibited to destruct forest protective infrastructures and means.

2) Everybody is given a business license to make use an area utilization, business license for environmental service utilization, business license for wood and non-wood product utilization, as well as license for wood and non-wood product collection, prohibited to conduct activities resulting in a forestry destruction.

3) Everybody is not permitted to :

a. manage and or make use and or occupy a forestry area in illegal way;

b. $\log$ forest area;

c.operate tree cutting in a forest area within radius or distance up to :

1. 500 (five hundreds) meters from dam or lake banks;

2. 200 (two hunderds) meters from well and river's right-and left-hand bank in swamp area;

3. 100 (one hundreds) meters from river's left-right bank.

4. 50 (fifty) meters from tributaries's left-right bank.

5. 2 (two) times of ravine depth from its bank.

6. 130 (one hundred thirty) times of differences between the highest and lowest tides.

d. slash and burn the forest;

e.cut trees or harvest or collect forestry products within it without any rights and permissions from the authorized officials.

f. receive, buy and sell, barter, accept consignment, store or possess forestry products that is understood or assumed coming from forest area where their harvesting and collecting is illegal;

g. make general investigation or exploration activities or exploitation of mining 
materials within forest area without any license from related Minister;

h. transport, hold, or take in forest product possession that is not simultaneously accompanied with documents about forest product's valid information letter;

i. tend livestocks within a forest area not specifically intended for such purposes by authorized officials;

j. bring heavy instruments and or tools that is not accepted generally or may be guessed to be used for forest product transportation within forest area without any permission from authorized officials.

k. bring instruments or tools that is generally made use to fell, cut, or divide trees within forest area without any permission from authorized officials.

l. discharge things or materials that may result in combustion and destruction as well as threaten forest function existence and continuity into forest area; and bring out and transport plants and wild animals which is not completed with regulatory protection coming from forest area without any permission from authorized officials.

Meanwhile, sanctions for any violations on norms as it is regulated within Article 50 of the 41 Act of 1999 said above, its general sanction specifications is established within Article 78. Briefly, the imposed criminal sanctions constitutes body criminal punishment as long as 15 years in jail, and its highest fine is Rp 10 billions.

The forest destructive protection through legal instruments by giving a repressive treatment for illegal logging actors must be improved.

With this repressive existence, thus it can be expected that it can prevent forest destructive actors for not doing again their illegal logging practice or forest destruction.

\section{Recovery}

The forest recovery is intended that there has occurred some destructed and deforested forests that result in erosion, consequence from illegal logging, shifting agriculture and illegal cutting by the HPH holder. It must be recovered to be preserved forest, so it can be again used and serve as life environmental ecosystem balancing factor and to be the world's lungs. This case may be conducted by replanting, both by government, community's collaborative actions or the HPH's holder.

\section{Conclusion}

1. That forest and forestry are strategic sectors because they are life supporting system in meaning that they can keep ecosystem equilibrium for life environmental preservation, both Indonesian and world interests. The forestry is also strategic sectors for economic, political, social, and cultural interests.

2. That judicial instrumental effectiveness through the 41 Act of 1999 can't actually prevent illegal cutting and logging in Indonesian's forest. 
3. That such judicial instrumental effectiveness is therefore not optimal to keep Indonesian's forest preservation for supporting its ecosystem equilibrium.

In fact, that forest and forestry in Indonesia, especially in Kalimantan, Sumatera, Sulawesi, and Papua where their total sizes has drastically perceived a reduction, and it is also occurred with its biological diversity.

There are some methods to prevent continuous forest destruction in Indonesia; one of them is to make effective forestry legal instrument and its enforcement. Furthermore, in attempt to recover those destructed forests, among other, it must immediately be implemented by replanting or reforestation activities.

1. Not effective

Do not assure appearance of life environmental preservation.

Bandung, May 2013

\section{Literature}

1. Bambang Pamuliardi, Hukum Kehutanan dan Pembangunan Bidang Kehutanan, PT. Raja Grafindo Persada Publisher, Jakarta, November 1994.

2. Bambang Sunggono, Metode Penelitian Hukum, Suatu Pengantar, PT. Raja Grafindo Persada Publisher, Jakarta, 1997.

3. I Made Widyana, dkk, (Editor), Bunga Rampai Pembangunan Hukum, PT. Eresco Publisher, Bandung, 1995.

4. Lexy J. Moleong, Metodologi Penelitian Kualitatif, Remaja Karya Publisher, Jakarta, 1989.

5. Salim, H.S., Dasar-Dasar Hukum Kehutanan, Sinar Grafika Mataram Publisher, 2002.

\section{Paper :}

Dudung Darusman, Peranan Hukum Tanaman Bagi Masa Depan Kehutanan Indonesia, Bandung, October 2008.

\section{Legislation}

The 41 Act of 1999 about Forestry.

\section{CURRICULUM VITAE}

Name

: Dr. Wahyu Wiriadinata 
Place of birth : Bandung,

Date of Birth $\quad: \quad 21^{\text {st }}$ October 1950

Address : Jl. Idi Adimadja I No. 1 Bandung

Occupation : - Lecturer for Post Graduate Program Padjadjaran University, Bandung.

- Lecture for Faculty of Law Pasundan University, Bandung. 